\title{
PENGARUH CORPORATE GOVERNANCE, PROFITABILITAS, UKURAN DAN KOMPLEKSITAS PERUSAHAAN TERHADAP AUDIT REPORT LAG
}

\author{
Elfina Astrella Sambuaga ${ }^{1}$ \\ Fakultas Ekonomi dan Bisnis, Universitas Pelita Harapan, Indonesia \\ elfina_sambuaga@yahoo.co.id
}

Olivia Putri Santoso ${ }^{2}$

Fakultas Ilmu Sosial dan Humaniora, Universitas Bunda Mulia, Indonesia

olivia.putri@mic.co.id

Diterima 1 Mei 2020

Disetujui 2 Juni 2020

\begin{abstract}
The purpose of this study to examine how agency theory plays a role in determining the factors that affect audit report lag. The difference in outcomes on factors affecting audit report lag in Indonesia and in Malaysia can be due to differences in corporate culture, economic environment, and existing regulations. The test is empirically focused on corporate governance, profitability, firm size and complexity for audit report lag both in Indonesia and Malay. The test uses multiple linear regression method with purposive sampling technique at 308 companies listed on Indonesia Stock Exchange and 361 companies at Bursa Malaysia for the period of 2015. Test results show that profitability called profit or loss of company is the main reason company to immediately publish its financial statement, thus reducing the occurrence of audit report lag. While other factors show different results in both countries. Especially for capital market authorities in Indonesia, it is necessary to consider efforts to improve the timeliness of financial reporting in Indonesia in order to improve the quality of the capital market in order to compete with other developing countries in the ASEAN region.
\end{abstract}

\section{Keywords: agency theory, audit report lag, corporate governance}

\section{PENDAHULUAN}

\subsection{Latar Belakang Masalah}

Adanya integrasi pasar modal ASEAN berupa penawaran saham lintas negara Asia Tenggara merupakan salah satu bentuk implementasi Masyarakat Ekonomi ASEAN di bidang pasar modal. Dari 10 negara ASEAN, hanya 3 negara yang telah sepakat untuk bergabung dalam program cross border offering produk investasi, yaitu Malaysia, Singapura, dan Thailand. Ketidakikutsertaan Indonesia dalam kesepakatan tersebut dikarenakan belum sinergisnya peraturan pasar modal yang ada serta pasar modal Indonesia yang masih tertinggal, baik dari sisi emiten maupun investornya, dibandingkan negara-negara tersebut (Koran Sindo, 2016).

Penawaran saham lintas negara ASEAN memungkinkan investor asing untuk menanamkan modalnya di Indonesia maupun sebaliknya. Salah satu upaya yang dapat dilakukan untuk melihat kesiapan pasar modal Indonesia yaitu meninjau kebijakan yang ada terkait pasar modal maupun sistem pelaporan keuangan perusahaan publik, karena laporan 
keuangan yang berkualitas dan disampaikan secara tepat waktu dapat menjadi salah satu faktor kunci keberhasilan investasi.

Emiten yang tercatat di pasar modal wajib mempublikasikan laporan keuangan auditannya dimana setiap negara memiliki regulasi tersendiri mengenai kewajiban penyampaian laporan tahunan. Di Indonesia, peraturan mengenai penyampaian laporan keuangan diatur dalam Surat Keputusan Badan Pengawas Pasar Modal Nomor KEP346/BL/2011 lampiran X.K.2 yang menyatakan bahwa perusahaan wajib menyampaikan laporan keuangan tahunan disertai laporan auditan kepada BAPEPAM paling lambat pada akhir bulan ketiga setelah tanggal tutup buku laporan keuangan tahunan. Sedangkan untuk negara lain seperti Malaysia, peraturan mengenai perusahaan yang tercatat di pasar modal, dapat dilihat di Bursa Malaysia Listing Requirement dimana untuk perusahaan yang tercatat di Bursa Malaysia wajib menerbitkan laporan tahunan beserta laporan auditan minimal 4 (empat) bulan di akhir tahun fiskal.

Perbedaan mengenai batas waktu penyampaian laporan keuangan perusahaan publik tersebut tidak mengurangi esensi dasar bahwa laporan keuangan harus disampaikan secara tepat waktu agar tidak kehilangan relevansinya, karena salah satu tujuan kualitatif dasar yang harus dimiliki laporan keuangan menurut APB Statement No. 4 adalah ketepatan waktu atau timeliness (Harahap, 2012). Pada tahun 2016, Bursa Efek Indonesia menghentikan sementara (suspend) perdagangan saham 18 emiten karena terlambat dalam menyampaikan laporan tahunannya (CNN Indonesia, 2016). Hal tersebut menunjukkan bahwa ketepatan waktu pelaporan keuangan perusahaan publik masih menjadi sasaran perbaikan otoritas pasar modal Indonesia.

\subsection{Rumusan Masalah}

Knechel dan Payne (2001) membagi tiga komponen dalam audit report lag, di antaranya adalah scheduling lag, fieldwork lag, dan reporting lag. Scheduling lag adalah selisih waktu antara akhir tahun fiskal perusahaan dengan dimulainya pekerjaan lapangan auditor. Fieldwork lag adalah selisih waktu antara dimulai dan berakhirnya pekerjaan lapangan auditor. Reporting lag merupakan selisih waktu antara tanggal laporan auditor dengan waktu penyelesaian pekerjaan lapangan. Scheduling lag menunjukkan bahwa jangka waktu audit report lag dipengaruhi oleh manajemen. Sedangkan fieldwork lag dan reporting lag menunjukkan peran auditor yang bertanggung jawab dalam melakukan proses pekerjaan lapangan hingga pembuat laporan audit, yang menyebabkan adanya audit report lag.

Penelitian sebelumnya tentang audit report lag yang dilakukan oleh Aristika, dkk. (2016) menemukan bahwa ukuran perusahaan serta laba atau rugi perusahaan memiliki pengaruh signifkan terhadap audit report lag. Haryani dan Wiratmaja (2014) menemukan bahwa komite audit dan kepemilikan publik memiliki pengaruh signifikan terhadap audit delay. Serta, Ariyani dan Budiartha (2014) menemukan adanya pengaruh antara audit report lag dengan ukuran perusahaan dan kompleksitas operasi.

Menurut agency theory, keberadaan anggota dewan dan komite audit merupakan salah satu alat pengawasan (monitoring) untuk mengurangi adanya agency problem, dimana mekanisme pengawasan salah satunya mengacu pada praktik corporate governance (Apadore dan Noor, 2013). Berdasarkan teori keagenan tersebutlah yang kemudian mendasari berkembangnya berbagai pemikiran mengenai Good Corporate Governance dimana pengelolaan perusahaan harus diawasi dan dikendalikan untuk memastikan bahwa pengelolaan dilakukan dengan penuh kepatuhan kepada peraturan dan ketentuan yang berlaku (Ramdhaningsih dan Utama, 2013). 


\subsection{Tujuan Penelitian}

Penelitian ini mengacu penelitian sebelumnya yang meneliti faktor-faktor yang mempengaruhi audit report lag pada perusahaan manufaktur di Indonesia dan Malaysia dari tahun 2009 hingga 2010. Hasil dari penelitian tersebut menunjukkan bahwa ukuran perusahaan, profitabilitas, laba/rugi perusahaan dan debt to equity ratio berpengaruh terhadap audit report lag di Indonesia dan Malaysia. Namun, faktor-faktor tersebut berbeda pada kedua negara, dimana audit report lag di Indonesia dipengaruhi oleh ukuran perusahaan dan debt to equity ratio. Sedangkan audit report lag di Malaysia hanya dipengaruhi oleh ukuran perusahaan. Oleh karena itu, penelitian ini akan mencoba meneliti kembali faktor-faktor yang mempengaruhi audit report lag di Indonesia dan Malaysia dengan melakukan beberapa pengembangan berdasarkan penelitian yang dilakukan oleh Hassan (2016) yang meneliti bagaimana agency theory berperan dalam menentukan faktor-faktor yang mempengaruhi audit report lag. Variabel independen dalam penelitian tersebut terdiri dari board size, corporate size, audit firm status, company complexity, existence of audit committee, CEO duality, ownership dispersion, ownership concentration.

\section{TINJAUAN PUSTAKA DAN HIPOTESIS \\ 2.1. Teori Keagenan (Agency Theory)}

Jensen dan Meckling (1976) mendefinisikan konsep keagenan sebagai kontrak yang terjadi antara principal (investor) dan agent (manajer). Hubungan keagenan terjadi saat principal menyewa agent untuk memberikan kontribusinya demi kepentingan mereka, dimana hal tersebut melibatkan pendelegasian wewenang untuk pengambilan keputusan kepada agent yang menyebabkan agent memiliki lebih banyak informasi tentang perusahaan dibandingkan principal.

Adanya ketimpangan informasi antara principal dan agent menyebabkan timbulnya beberapa permasalahan keagenan, diantaranya asimetri informasi (Wardhani dan Raharja, 2013). Hal ini menunjukkan bahwa tidak selamanya manajer bertindak sesuai dengan kepentingan pemilik perusahaan, melainkan adanya konflik kepentingan dimana mereka bertindak demi kepentingan mereka sendiri (Ramdhaningsih dan Utama, 2013).

Berdasarkan teori keagenan tersebutlah yang kemudian mendasari berkembangnya berbagai pemikiran mengenai Good Corporate Governance dimana pengelolaan perusahaan harus diawasi dan dikendalikan untuk memastikan bahwa pengelolaan dilakukan dengan penuh kepatuhan kepada peraturan dan ketentuan yang berlaku (Ramdhaningsih dan Utama, 2013).

\subsection{Good Corporate Governance}

The Indonesia Corporate Governance Manual mendefinisikan corporate governance sebagai suatu sistem atau struktur dalam perusahaan yang menaungi hubungan antara pihakpihak yang memiliki kepentingan berbeda untuk memastikan terjaminnya pembagian hak serta kewajiban manajemen maupun pemegang sahan untuk meningkatkan shareholder value dalam jangka panjang.

Bursa Malaysia menekankan pentingnya peran good corporate governance dalam perusahaan untuk menjamin terpenuhinya ketepatan waktu pelaporan keuangan (Hashim dan Rahman, 2011). 


\subsection{Audit Report Lag}

Audit report lag merupakan jangka waktu yang diukur menggunakan jumlah hari, dari tanggal penutupan tahun buku sampai dengan tanggal diterbitkannya laporan audit independen (Ashton, et al., 1987).

Menurut Dyer dan Mchugh (1975) dalam Widhiasari dan Budiartha (2016), terdapat 3 kriteria dalam melihat ketepatan waktu pelaporan keuangan, yakni:

1. Preliminary lag adalah rentan waktu yang dihitung dengan jumlah hari antara tanggal laporan keuangan sampai penerimaan laporan akhir preliminary yang diterima di bursa.

2. Auditor's report lag adalah rentan waktu yang dihitung dengan jumlah hari antara tanggal laporan keuangan sampai tanggal auditor menandatangani laporan hasil audit.

3. Total lag adalah jumlah hari dari tanggal selesai laporan keuangan sampai tanggal publikasi di bursa.

Knechel dan Payne (2001) dalam Widhiasari dan Budiartha (2016) membagi tiga komponen audit report lag, dimana:

1. Scheduling lag adalah selisih waktu antara akhir tahun fiskal atau tanggal neraca perusahaan hingga dimulainya pekerjaan lapangan oleh auditor.

2. Fieldwork lag adalah selisih waktu antara dimulainya pekerjaan lapangan auditor hingga saat penyelesaiannya.

3. Reporting lag adalah selisih waktu antara penyelesaian pekerjaan lapangan auditor hingga terbitnya laporan audit.

Jadi, berdasarkan kriteria di atas, scheduling lag menunjukkan bahwa jangka waktu audit report lag yang dipengaruhi oleh manajemen, sedangkan fieldwork lag dan reporting lag menjadi tanggung jawab auditor yang melakukan pekerjaan lapangan sekaligus menerbitkan laporan audit.

Di Indonesia, peraturan mengenai penyampaian laporan keuangan diatur dalam Surat Keputusan Badan Pengawas Pasar Modal Nomor KEP-346/BL/2011 lampiran X.K.2 yang menyatakan bahwa perusahaan wajib menyampaikan laporan keuangan tahunan disertai laporan auditan kepada BAPEPAM paling lambat pada akhir bulan ketiga setelah tanggal laporan keuangan tahunan. Sedangkan untuk Malaysia, peraturan mengenai perusahaan yang tercatat di pasar modal, dapat dilihat di Bursa Malaysia Listing Requirement Chapter 9.23 yang mewajibkan perusahaan yang tercatat di Bursa Malaysia wajib menerbitkan laporan tahunan beserta laporan auditan paling lambat 4 (empat) bulan setelah akhir tahun fiskal.

\subsection{Pengembangan Hipotesis}

\subsubsection{Pengaruh Board Size Terhadap Audit Report Lag}

Dewan direksi memegang peranan penting dalam meningkatkan efektivitas pelaporan keuangan dalam suatu organisasi (Bezemer, et al., 2014). Menurut Plessis, et al (2012) pemisahan antara ownership dan control dalam teori keagenan dapat menyebabkan agency problem, dimana untuk mengurangi masalah tersebut, dibentuklah suatu dewan (board) sebagai alat monitoring.

Dalam sistem tata kelola perusahaan, terdapat dua sistem dewan, yaitu one-tier dan twotier board. Dalam one-tier system, dewan direksi terdiri dari satu badan tunggal yang beranggotakan direktur non-eksekutif yang bertugas memegang peran pengawasan dan direktur eksekutif yang memegang kendali atas manajemen perusahaan. Sedangkan dalam two-tier system, dewan dalam perusahaan terdiri dari dewan direksi (board of directors) yang bertanggung jawab dalam manajemen perusahaan dan dewan komisaris (board of commissioner) yang bertanggung jawab dalam pengawasan perusahaan (Plessis et al, 2012). 
Agency theory mengusulkan bahwa seharusnya ada batas maksimal dalam jumlah keanggotaan suatu dewan dimana board size yang besar dapat menimbulkan masalah dalam komunikasi dan koordinasinya (Hassan 2016). Hal ini didukung oleh penelitian sebelumnya yang dilakukan oleh Hassan (2016) di Palestina serta Wardhani dan Raharja (2013) di Indonesia bahwa jumlah anggota dewan yang semakin besar akan memperpanjang audit report lag.

Sebaliknya, penelitian yang dilakukan oleh Alfraih (2016) pada perusahaan terdaftar di Kuwait menemukan bahwa board size justru berpengaruh negatif terhadap audit report lag dan mengimplikaksikan bahwa board size yang lebih besar dan beragam dapat meningkatkan kualitas laporan keuangan sehingga jangka waktu terbitnya laporan audit akan lebih pendek. Sejalan dengan agency theory yang dijelaskan di atas, maka hipotesis yang diajukan adalah:

$\mathrm{H}_{1}$ : Board size akan meningkatkan audit report lag pada perusahaan di Indonesia.

$\mathrm{H}_{7}$ : Board size akan meningkatkan audit report lag pada perusahaan di Malaysia.

\subsubsection{Pengaruh Komite Audit Terhadap Audit Report Lag}

Menurut Hashim dan Rahman (2011), adanya komite audit dalam organisasi berperan penting untuk meningkatkan ketepatan waktu pelaporan keuangan perusahaan. Menurut Peraturan BAPEPAM No. IX.I.5 mengenai Pembentukan dan Pedoman Pelaksanaan Kerja Komite Audit menjelaskan bahwa komite audit sekurangnya terdiri dari 3 (tiga) orang anggota yang berasal dari Komisaris Independen dan pihak lain dari luar Emiten atau perusahaan publik. Di Malaysia, aturan mengenai komite audit diatur dalam Bursa Malaysia Listing Requirement Chapter 13.5.

Penelitian sebelumnya yang dilakukan oleh Hassan (2016) dan Puasa, et al. (2014) menyatakan bahwan komite audit berpengaruh negatif terhadap audit report lag dan menyatakan bahwa efektivitas komite audit akan meningkatkan kualitas laporan keuangan sehingga mengurangi audit report lag. Hal ini juga didukung oleh penelitian sebelumnya yang dilakukan oleh Apadore dan Noor (2013), Ayushabrina dan Rahardjo (2014), serta Haryani dan Wiratmaja (2014). Sedangkan penelitian yang dilakukan oleh Wardhani dan Raharja (2013) serta Angruningrum dan Wirakusuma (2013) menyatakan komite audit tidak berpengaruh terhadap audit report lag. Maka hipotesis yang diajukan:

$\mathrm{H}_{2}$ : Jumlah komite audit akan mengurangi audit report lag pada perusahaan di Indonesia.

$\mathrm{H}_{8}$ : Jumlah komite audit akan mengurangi audit report lag pada perusahaan di Malaysia.

\subsubsection{Pengaruh Ownership Concentration Terhadap Audit Report Lag}

Perusahaan dengan kepemilikan saham menyebar diharapkan mampu menyajikan laporan keuangan yang lebih berkualitas dibandingkan perusahaan dengan kepemilikan saham terkonsentrasi yang cenderung menyajikan pengungkapan (disclosure) yang buruk (Hassan, 2016). Hal tersebut dikarenakan major shareholders cenderung memiliki akses langsung terhadap informasi internal perusahaan. Sehingga perusahaan dengan struktur kepemilikan terkonsentrasi, cenderung lebih lama dalam mempublikasikan laporan keuangannya (Ashton et al. 1987 dalam Apadore dan Noor, 2013).

Penelitian sebelumnya yang dilakukan oleh Hassan (2016) menemukan bahwa ownership concentration memiliki arah hubungan yang positif namun tidak signifikan terhadap audit report lag, sedangkan Apadore dan Noor (2013) menemukan bahwa ownership concentration berpengaruh positif terhadap audit report lag. Berdasarkan uraian diatas, maka hipotesis yang diajukan adalah sebagai berikut: 
$\mathrm{H}_{3}$ : Adanya ownership concentration akan meningkatkan audit report lag pada perusahaan di Indonesia.

$\mathrm{H}_{9}$ : Adanya ownership concentration akan meningkatkan audit report lag pada perusahaan di Malaysia.

\subsubsection{Pengaruh Laba atau Rugi Tahun Berjalan Terhadap Audit Report Lag}

APB Statement mendefinisikan laba (rugi) sebagai kelebihan (defisit) penghasilan di atas biaya selama satu periode akuntansi. Pengukuran laba tidak hanya penting untuk menentukan kinerja perusahaan, tetapi juga penting sebagai informasi bagi pembagian laba dan penentuan kebijakan investasi. Perusahaan yang mengalami laba akan cenderung lebih cepat dalam mempublikasikan laporan keuangannya karena hal tersebut dianggap sebagai good news bagi para shareholders maupun investor (Indriyani dan Supriyati, 2012). Laba perusahaan dapat mencermikan kinerja perusahaan yang baik (Ayushabrina dan Rahardjo, 2014).

Penelitian sebelumnya yang dilakukan oleh Shukeri dan Islam (2012), Aristika, dkk. (2016) menemukan bahwa laba atau rugi tahun berjalan berpengaruh negatif terhadap audit report lag, yang artinya perusahaan yang mengalami laba akan cenderung mempublikasikan laporan keuangannya lebih cepat. Sedangkan penelitian yang dilakukan oleh Ayushabrina dan Rahardjo (2014) serta Indriyani dan Supriyati (2012) menemukan bahwa laba atau rugi tahun berjalan tidak berpengaruh signifikan terhadap audit report lag. Oleh karena itu, hipotesis yang diajukan adalah:

$\mathrm{H}_{4}$ : Laba tahun berjalan akan mengurangi audit report lag pada perusahaan di Indonesia.

$\mathrm{H}_{10}$ : Laba tahun berjalan akan mengurangi audit report lag pada perusahaan di Malaysia

\subsubsection{Pengaruh Ukuran Perusahaan Terhadap Audit Report Lag}

Ukuran perusahaan dapat dilihat dari total aset, total penjualan, jumlah tenaga kerja atau karyawan. Ukuran perusahaan yang digunakan dapat dilihat dan dihitung dari natural log total asetnya. Menurut Sari dan Gozhali (2014), perusahaan yang lebih besar cenderung lebih cepat menyelesaikan laporan keuangan auditnya karena mereka memiliki kepentingan yang menuntut mereka untuk segera menerbitkan laporan keuangannya, sehingga ukuran perusahaan berpengaruh negatif terhadap audit report lag.

Hassan (2016), Alfraih (2016), Ayushabrina dan Rahardjo (2014), serta Ariyani dan Budiartha (2014) menemukan bahwa ukuran perusahaan berpengaruh negatif terhadap audit report lag. Sedangkan Haryani dan Wiratmaja (2014) dan Wardhani dan Raharja (2013) menemukan bahwa ukuran perusahaan tidak berpengaruh terhadap audit report lag. Maka hipotesis yang diajukan:

$\mathrm{H}_{5}$ : Ukuran perusahaan akan mengurangi audit report lag pada perusahaan di Indonesia.

$\mathrm{H}_{11}$ : Ukuran perusahaan akan mengurangi audit report lag pada perusahaan di Malaysia.

\subsubsection{Pengaruh Kompleksitas Perusahaan Terhadap Audit Report Lag}

Menurut Ashton, et al. (1987), perusahaan dengan kompleksitas operasi yang lebih tinggi cenderung mempublikasikan laporan keuangan mereka lebih lama karena auditor eksternal membutuhkan waktu yang lebih lama dalam mengaudit laporan keuangannya.

Pengukuran kompleksitas perusahaan dapat dilihat dengan dua cara yaitu kompleksitas operasi yang dapat dihitung menggunakan jumlah entitas (Hassan, 2016). Kompleksitas organisasi atau operasi merupakan akibat dari pembentukan departemen dan pembagian pekerjaan yang memiliki fokus terhadap jumlah unit yang berbeda (Ariyani dan Budiartha, 2014). 
Penelitian sebelumnya yang dilakukan oleh Ariyani dan Budiartha (2014), berargumen bahwa perusahaan yang lebih komlpleks operasinya akan cenderung menghasilkan audit report lag yang lebih panjang. Sebaliknya, penelitian yang dilakukan oleh Hassan (2016) menemukan bahwa kompleksitas perusahaan berpengaruh negatif terhadap audit report lag. Hal tersebut dapat dikarenakan perusahaan dengan kompleksitas operasi yang lebih tinggi biasanya memiliki sistem pelaporan yang lebih baik. Penelitian lain yang dilakukan oleh Alfraih (2016) serta Wardhani dan Raharja (2013) menemukan bahwa kompleksitas perusahaan tidak berpengaruh terhadap audit report lag. Maka hipotesis yang diajukan adalah:

$\mathrm{H}_{6}$ : Adanya kompleksitas perusahaan akan meningkatkan audit report lag pada perusahaan di Indonesia.

$\mathrm{H}_{12}$ : Adanya kompleksitas perusahaan akan meningkatkan audit report lag pada perusahaan di Malaysia.

\section{METODE PENELITIAN}

\subsection{Subjek dan Objek Penelitian}

Penelitian ini menggunakan perusahaan non-financial yang terdaftar di Bursa Efek Indonesia dan Bursa Malaysia tahun 2015. Indonesia dan Malaysia dipilih karena keduanya merupakan negara berkembang di ASEAN namun terdapat perbedaan, salah satunya dari segi performance pasar modalnya. Indonesia masih cukup tertinggal dibandingkan dengan Malaysia dan hal tersebut mungkin dapat disebabkan oleh perbedaan pada regulasi maupun sistem tata kelolanya. Selain itu, alasan pengecualian perusahaan non-financial adalah karena sektor ini memiliki struktur keuangan dan persyaratan serta kebijakan pelaporan keuangannya pun berbeda dengan sektor lain.

Dalam pengambilan sampel menggunakan teknik pengambilan data purposive sampling dengan pertimbangan tertentu yang telah disesuaikan. Sesuai dengan kriteria pemilihan sampe, maka diperoleh 308 perusahaan yang berasal dari Bursa Efek Indonesia, dan 361 perusahaan dari Bursa Malaysia. Terdapat tujuh variabel dalam penelitian ini yang terdiri dari satu variabel dependen dan enam variabel independen yang dijelaskan dalam tabel 3.1

Tabel 3.1

\section{Operasional Variabel}

\begin{tabular}{|c|c|}
\hline Variabel & Indikator \\
\hline $\begin{array}{l}\text { Audit Report Lag } \\
\text { (ARL) }\end{array}$ & $\begin{array}{l}\text { selisih waktu antara tanggal tutup buku perusahaan dengan tanggal yang tercantum } \\
\text { dalam laporan auditor independen yang diukur menggunakan jumlah hari (Hassan, } \\
\text { 2016). }\end{array}$ \\
\hline $\begin{array}{l}\text { Jumlah anggota dewan } \\
\text { (BSIZE) }\end{array}$ & Jumlah anggota dewan yang ada dalam suatu perusahaan \\
\hline $\begin{array}{l}\text { Komite audit } \\
\text { (AUDCOM) }\end{array}$ & $\begin{array}{l}\text { Jumlah anggota komite audit yang ada dalam suatu perusahaan (Apadore dan Noor, } \\
\text { 2013). }\end{array}$ \\
\hline $\begin{array}{l}\text { Ownership } \\
\text { Concentration } \\
\text { (OWNCON) }\end{array}$ & $\begin{array}{l}\text { Konsentrasi kepemilikan yang diukur berdasarkan jumlah shareholders yang } \\
\text { memiliki saham biasa sebesar 5\% atau lebih (Hassan, 2016). }\end{array}$ \\
\hline $\begin{array}{l}\text { Laba atau rugi tahun } \\
\text { berjalan } \\
\text { (PROFIT) }\end{array}$ & $\begin{array}{l}\text { Laba atau rugi perusahaan pada tahun berjalan yang diproksikan dengan } d u m m y . \\
\text { Bernilai } 1 \text { jika perusahaan mengalami laba, dan } 0 \text { jika perusahaan mengalami rugi } \\
\text { (Ayushabrina dan Rahardjo, 2014) }\end{array}$ \\
\hline $\begin{array}{l}\text { Ukuran Perusahaan } \\
\text { (SIZE) }\end{array}$ & $\begin{array}{l}\text { Ukuran perusahaan yang diukur dengan logaritma natural total aset (Indriyani dan } \\
\text { Supriyati, 2012). }\end{array}$ \\
\hline $\begin{array}{l}\text { Kompleksitas } \\
\text { Perusahaan } \\
\text { (COMPLX) }\end{array}$ & $\begin{array}{l}\text { Kompleksitas perusahaan yang diukur dengan square root jumlah anak perusahaan } \\
\text { (subsidiary) (Wardhani dan Raharja, 2013). }\end{array}$ \\
\hline
\end{tabular}




\subsection{Model Penelitian}

Model yang digunakan dalam penelitian ini adalah sebagai berikut:

$$
\begin{aligned}
\mathrm{ARL}= & \beta_{0}+\beta_{1} \mathrm{BSIZE}+\beta_{2} \mathrm{AUDCOM}+\beta_{3} \mathrm{OWNCON}+\beta_{4} \mathrm{PROFIT}+\beta_{5} \mathrm{SIZE}+ \\
& \beta_{6} \mathrm{COMPLX}+\varepsilon
\end{aligned}
$$

Dimana:

ARL: $\quad$ selisih waktu antara tanggal tutup buku perusahaan dengan tanggal yang tercantum dalam laporan auditor independen (audit report lag) yang diukur menggunakan jumlah hari.

BSIZE: Jumlah anggota dewan, yaitu jumlah dewan yang ada pada perusahaan

AUDCOM: Komite audit, yaitu jumlah komite audit yang ada pada perusahaan

OWNCON: Ownership concentration, yaitu konsentrasi kepemilikan yang diukur berdasarkan jumlah shareholders yang memiliki 5\% atau lebih saham biasa

PROFIT: $\quad$ Laba atau Rugi Tahun Berjalan, yang diproksikan dengan dummy, dimana "1" jika perusahaan mengalami laba, dan "0" jika perusahaan mengalami rugi

SIZE: $\quad$ Ukuran perusahaan, yang diproksikan dengan logaritma natural total aset

COMPLX: Kompleksitas perusahaan, yang diproksikan dengan menghitung square root jumlah subsidiary

e: $\quad$ error

\section{HASIL PENELITIAN DAN DISKUSI}

\subsection{Statistik Deskriptif}

Analisis statistik deskriptif dilakukan untuk memberikan gambaran mengenai objek data yang diteliti, dapat dilihat pada tabel berikut.

Tabel 5.1

Statistik Deskriptif (Indonesia)

\begin{tabular}{llllll}
\hline & $\mathrm{N}$ & Minimum & Maximum & Mean & Std. Deviation \\
\hline ARL & 308 & 29 & 138 & 79,62 & 15,588 \\
BSIZE & 308 & 4 & 28 & 8,99 & 3,372 \\
AUDCOM & 308 & 2 & 5 & 3,07 &, 377 \\
OWNCON & 308 & 1 & 7 & 2,60 & 1,492 \\
SIZE & 308 & 23,06030 & 33,13405 & 28,3753428 & 1,67859587 \\
COMPLX & 308 &, 0000 & 21,0238 & 2,557906 & 2,3230836 \\
\hline $\mathrm{N}$ & 308 & \multicolumn{5}{l}{} \\
\hline
\end{tabular}

Tabel 5.2

Statistik Deskriptif (Malaysia)

\begin{tabular}{llllll}
\hline & $\mathrm{N}$ & Minimum & Maximum & Mean & Std. Deviation \\
\hline ARL & 361 & 34 & 120 & 91,17 & 17,915 \\
BSIZE & 361 & 4 & 12 & 7,32 & 1,643 \\
AUDCOM & 361 & 3 & 5 & 3,27 &, 520 \\
OWNCON & 361 & 1 & 7 & 2,71 & 1,241 \\
SIZE & 361 & 17,00571 & 24,75073 & 20,1955061 & 1,51573732 \\
COMPLX & 361 &, 0000 & 13,2665 & 3,925477 & 2,1821355 \\
\hline $\mathrm{N}$ & 361 & \multicolumn{5}{c}{} \\
\hline
\end{tabular}


Tabel 5.3

Distribusi Frekuensi Laba atau Rugi (Indonesia)

\begin{tabular}{llllll}
\hline \multirow{2}{*}{ Variabel } & Kategori & Indonesia & \multicolumn{3}{c}{ Malaysia } \\
\cline { 3 - 6 } PROFIT & Rugi & 88 & 28,6 & 85 & 23,5 \\
& Laba & 220 & 71,4 & 276 & 76,5 \\
\cline { 2 - 6 } & Total & 308 & 100,0 & 361 & 100,0 \\
\hline
\end{tabular}

Tabel 5.1 menunjukkan hasil analisis statistik deskriptif untuk 308 sampel penelitian di Indonesia tahun 2015. Dari hasil tersebut, dapat dilihat bahwa rata-rata audit report lag di Indonesia adalah sebesar 80 hari dengan nilai minimal 29 hari dan maksimal 138 hari. Terdapat 17 perusahaan yang memiliki audit report lag melampaui batas waktu penyampaian yang telah ditetapkan, sedangkan sisanya sebanyak 291 perusahaan masih memenuhi ketentuan yang ada. Sehingga, dapat disimpulkan bahwa meskipun masih ada perusahaan yang melewati batas penyampaian laporan keuangan yang telah ditetapkan oleh BAPEPAM yaitu akhir bulan ketiga setelah tanggal tutup buku, rata-rata perusahaan sampel di Indonesia telah memenuhi ketentuan tersebut.

Sebagai perbandingan, rata-rata audit report lag di Indonesia cenderung lebih panjang bandingkan dengan penelitian sebelumnya yang dilakukan oleh Hassan (2016) di Palestina, dimana rata-rata audit report lag di negara tersebut hanya 62 hari dengan minimal audit report lag 17 hari dan maksimal 96 hari.

Selanjutnya, jumlah anggota dewan di Indonesia beranggotakan paling sedikit 4 orang dan paling banyak 28 orang dengan rata-rata 9 orang. Jumlah anggota komite audit di Indonesia bervariasi antara 2 hingga 5 orang anggota dengan rata-rata 3 orang anggota komite audit. Sebanyak 8 perusahaan hanya memiliki 2 orang anggota komite audit, sedangkan sisanya 300 perusahaan memiliki 3 orang anggota atau lebih. Hal tersebut berarti rata-rata jumlah anggota komite audit pada perusahaan sampel penelitian telah memenuhi kriteria jumlah minimal anggota komite audit yaitu 3 anggota, meskipun masih ada 8 perusahaan yang hanya memiliki 2 anggota komie audit dan belum memenuhi kriteria minimal yang ditetapkan oleh BAPEPAM.

Selain itu, untuk variabel ownership concentration, jumlah pemegang saham yang memiliki 5\% saham atau lebih bervariasi antara 1 hingga 7 shareholders dengan rata-rata 2,6 shareholders. Ukuran perusahaan yang diukur berdasarkan natural log total aset memiliki nilai minimal 23,0603 dan nilai maksimal 33,13405 dengan rata-rata sebesar 28,3753428. Dan kompleksitas perusahaan yang diukur dengan menghitung square root jumlah anak perusahaan memiliki nilai minimal 0 dan nilai maksimal 21,0238 dan nilai rata-rata 2,557906. Sebanyak 262 perusahaan memiliki anak perusahaan sedangkan sisanya 46 perusahaan tidak memiliki anak perusahaan.

Tabel 5.2 menunjukkan hasil analisis statistik deskriptif untuk 361 perusahaan sampel di Malaysia tahun 2015. Dari hasil tersebut, dapat dilihat bahwa rata-rata audit report lag di Malaysia adalah sebesar 91 hari dengan nilai minimal 34 hari dan maksimal 120 hari. Hal tersebut menunjukkan bahwa meskipun rata-rata audit report lag di Malaysia lebih panjang dibandingkan dengan di Indonesia (91 hari di Malaysia dan 80 hari di Indonesia), maksimal audit report lag pada perusahaan sampel di Malaysia adalah 120 hari, yang berarti tidak ada perusahaan sampel di Malaysia yang melampaui batas penyampaian laporan keuangan yang ditetapkan Bursa Malaysia Listing Requirement yaitu akhir bulan keempat setelah tanggal tutup buku perusahaan atau 120 hari.

Selanjutnya, jumlah anggota dewan di Malaysia beranggotakan paling sedikit 4 orang dan paling banyak 12 orang dengan rata-rata 9 orang. Jumlah anggota komite audit di Malaysia 
bervariasi antara 3 hingga 5 orang anggota dengan rata-rata 3 orang anggota komite audit. Hal itu berarti seluruh perusahaan sampel telah memenuhi kriteria minimal jumlah anggota komite audit yang ditetapkan Bursa Malaysia Listing Requirement yaitu 3 orang anggota.

Untuk variabel ownership concentration, jumlah pemegang saham yang memiliki 5\% saham atau lebih bervariasi antara 1 hingga 7 shareholders dengan rata-rata 2,71 shareholders. Ukuran perusahaan yang diukur berdasarkan natural log total aset memiliki nilai minimal 17,00571 dan nilai maksimal 24,75073 dengan rata-rata sebesar 20,1955061. Dan kompleksitas perusahaan yang diukur dengan menghitung square root jumlah anak perusahaan memiliki nilai minimal 0 dan nilai maksimal 13,2665 dan nilai rata-rata 3,925477. Sebanyak 7 perusahaan tidak memiliki anak perusahaan, sedangkan sisanya 354 perusahaan memiliki anak perusahaan.

Tabel 5.3 menunjukkan statistik deskriptif untuk variabel laba atau rugi tahun berjalan yang diproksikan dengan dummy. Dapat dilihat bahwa dari 308 perusahaan sampel di Indonesia tahun 2015,88 perusahaan atau sekitar $28,6 \%$ perusahaan mengalami rugi dan sisanya 220 perusahaan atau sekitar 71,4\% perusahaan mengalami laba. Sedangkan, dari 361 perusahaan sampel di Malaysia tahun 2015, sebanyak 85 perusahaan atau sekitar 23,5\% perusahaan mengalami rugi dan sisanya 276 perusahaan atau sekitar 76,5\% perusahaan mengalami laba. Oleh karena itu, dapat disimpulkan bahwa kinerja perusahaan di Indonesia dan Malaysia pada tahun 2015 dianggap cukup baik, jika dilihat dari laba atau rugi yang dialami perusahaan.

\subsection{Analisis Regresi Linier Berganda}

Tabel 5.4

Summary Hasil Regresi Kelompok Sampel di Indonesia

\begin{tabular}{|c|c|c|c|c|c|}
\hline \multicolumn{6}{|c|}{$\begin{array}{l}\text { ARL }{ }_{I N A}=103,882-1,030 B S I Z E-0,812 \text { AUDCOM + 1,257OWNCON - 8,322PROFIT - } \\
\text { 0,366SIZE + 0,210COMPLX }\end{array}$} \\
\hline \multicolumn{6}{|c|}{ Dependent Variable $=$ Audit Report Lag } \\
\hline Independent Variable & $\begin{array}{l}\text { Expected } \\
\text { sign }\end{array}$ & Coefficients & t-stat & $\begin{array}{l}\text { p-value } \\
\text { (1 tailed })\end{array}$ & $V I F$ \\
\hline Constant & & 103,882 & 5,358 & 0,000 & \\
\hline BSIZE & $(+)$ & $-1,030$ & $-3,171$ & $\mathbf{0 , 0 0 1} *$ & 1,770 \\
\hline AUDCOM & $(-)$ & $-0,812$ & $-0,347$ & 0,384 & 1,144 \\
\hline OWNCON & $(+)$ & 1,257 & 2,237 & $0,013 *$ & 1,038 \\
\hline PROFIT & $(-)$ & $-8,322$ & $-4,497$ & $0,000 *$ & 1,035 \\
\hline SIZE & $(-)$ & $-0,366$ & $-0,497$ & 0,309 & 2,253 \\
\hline COMPLX & $(+)$ & 0,210 & 0,495 & 0,315 & 1,433 \\
\hline \multicolumn{2}{|l|}{ F-Test } & 0,000 & & & \\
\hline \multicolumn{2}{|l|}{ Adjusted $R^{2}$} & 0,144 & & & \\
\hline \multicolumn{2}{|c|}{$\mathbf{N}$} & 308 & & & \\
\hline \multicolumn{6}{|c|}{ 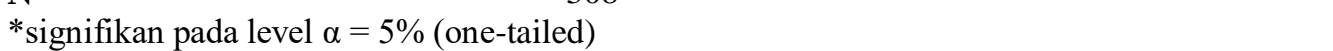 } \\
\hline
\end{tabular}

Sumber : Hasil olahan Penulis

\section{PEMBAHASAN HIPOTESIS}

\subsection{Pengaruh Board Size Terhadap Audit Report Lag di Indonesia}

Jumlah anggota dewan memiliki tingkat signifikansi sebesar 0,001 yang berarti lebih kecil dari tingkat signifikansi ( $\mathrm{Sig}>0,05$ ), maka dapat disimpulkan bahwa board size berpengaruh negatif dan signifikan terhadap audit report lag di Indonesia, sehingga $\mathrm{H}_{1}$ yang menyatakan board size akan meningkatkan audit report lag di Indonesia ditolak, karena berbeda dengan dugaan awal bahwa board size pada perusahaan dapat menyebabkan masalah koordinasi dan kurang efektifnya kinerja dewan yang ada sehingga akan memperpanjang audit report lag, hasil penelitian justru menunjukkan bahwa semakin banyak board size justru akan mengurangi audit report lag. 
Hal ini sejalan dengan hasil penelitian sebelumnya yang dilakukan oleh Alfraih (2016) yang menemukan adanya hubungan negatif dan signifikan antara board size dengan audit report lag. Tetapi, penelitian ini tidak mendukung hasil penelitian yang dilakukan oleh Hassan (2016) dan Wardhani dan Raharja (2013) yang menemukan bahwa board size berpengaruh positif dengan audit report lag. Hal tersebut mungkin disebabkan karena semakin banyak board size dengan latar belakang keahlian yang beragam, justru dapat meningkatkan kualitas laporan keuangan sehingga dapat memperpendek audit report lag. Selain itu, board size yang lebih maksimal mampu berkontribusi lebih dalam meningkatkan kualitas laporan keuangan, serta ketepatan waktunya.

\subsection{Pengaruh Komite Audit Terhadap Audit Report Lag di Indonesia}

Komite audit memiliki tingkat signifikansi 0,384 yang berarti lebih besar dari tingkat signifikansi (Sig > 0,05) maka dapat disimpulkan bahwa komite audit tidak memiliki pengaruh signifikan terhadap audit report lag di Indonesia, sehingga $\mathrm{H}_{2}$ yang menyatakan jumlah komite audit akan mengurangi audit report lag di Indonesia ditolak.

Hal tersebut dikarenakan hasil penelitian tidak menunjukkan adanya pengaruh yang signifikan antara komite audit dengan audit report lag. Hal ini mungkin disebabkan karena penelitian ini hanya mengukur efektivitas komite audit berdasarkan jumlah anggotanya dan tidak menggunakan pengukuran lain seperti independensi, kualifikasi, maupun jumlah pertemuan komite audit yang dapat lebih berkontribusi dalam meningkatkan kualitas laporan keuangan untuk dapat mengurangi audit report lag perusahaan.

Hasil penelitian ini mendukung hasil penelitian sebelumnya yang dilakukan oleh Wardhani dan Raharja (2013) serta Angruningrum dan Wirakusuma (2013) yang menemukan bahwa komite audit tidak berpengaruh signifikan terhadap audit report lag. Penelitian ini tidak mendukung hasil penelitian yang dilakukan oleh Hassan (2016) dan Puasa, et al., (2014) yang menemukan bahwa jumlah serta efektivitas komite audit dapat mengurangi audit report lag.

\subsection{Pengaruh Ownership Concentration Terhadap Audit Report Lag di Indonesia}

Ownership concentration memiliki tingkat signifikansi 0,013 yang berarti lebih kecil dari tingkat signifikansi (Sig > 0,05) maka dapat disimpulkan bahwa ownership concentration memiliki pengaruh signifikan positif terhadap audit report lag di Indonesia, sehingga $\mathrm{H}_{3}$ yang menyatakan adanya konsentrasi kepemilikan akan meningkatkan audit report lag di Indonesia tidak ditolak. Hal tersebut dikarenakan major shareholders cenderung memiliki akses langsung terhadap informasi internal perusahaan, serta perusahaan dengan kepemilikan yang terkonsentrasi, cenderung memiliki kualitas pelaporan serta pengungkapan yang rendah sehingga akan meningkatkan audit report lag.

Hasil penelitian ini mendukung penelitian sebelumnya yang dilakukan oleh Apadore dan Noor (2013) yang menemukan adanya hubungan positif dan signifikan antara komite audit dan audit report lag yang menyatakan banyaknya jumlah pemegang saham blockholder dapat mengakibatkan semakin banyaknya intervensi dalam pelaporan keuangannya dan meningkatkan audit report lag.

\subsection{Pengaruh Laba Tahun Berjalan Terhadap Audit Report Lag di Indonesia}

Laba tahun berjalan memiliki tingkat signifikansi 0,000 yang berarti lebih kecil dari tingkat signifikansi (sig > 0,05) maka dapat disimpulkan bahwa laba atau rugi tahun berjalan memiliki pengaruh signifikan negatif terhadap audit report lag di Indonesia, sehingga $\mathrm{H}_{4}$ yang menyatakan bahwa laba tahun berjalan akan mengurangi audit report lag di Indonesia tidak ditolak. Hal tersebut dikarenakan laba mencerminkan kinerja perusahaan yang baik dan dianggap sebagai good news bagi manajemen maupun investor, sehingga perusahaan akan cenderung sesegera mungkin mempublikasikan laporan keuangannya. 
Hasil penelitian ini mendukung penelitian sebelumnya yang dilakukan oleh Aristika dkk., (2016) serta Shukeri dan Islam (2012) yang menemukan bahwa laba tahun berjalan akan mengurangi audit report lag, yang berarti perusahaan yang mengalami laba, akan cenderung mempublikasikan laporan keuangannya lebih cepat. Selain itu, hasil penelitian ini tidak memberikan bukti yang mendukung penelitian yang dilakukan oleh Ayushabrina dan Raharjo (2014) serta Indriyani dan Supriyati (2012) yang menyatakan bahwa tidak ada pengaruh yang signifikan antara laba tahun berjalan dengan audit report lag, baik di Indonesia maupun Malaysia.

\subsection{Pengaruh Ukuran Perusahaan Terhadap Audit Report Lag di Indonesia}

Ukuran perusahaan memiliki tingkat signifikansi 0,309 yang berarti lebih besar dari tingkat signifikansi $(\mathrm{Sig}>0,05)$ maka dapat dilihat bahwa ukuran perusahaan tidak memiliki pengaruh signifikan terhadap audit report lag di Indonesia, sehingga $\mathrm{H}_{5}$ yang menyatakan bahwa ukuran perusahaan akan mengurangi audit report lag di Indonesia ditolak.

Hal tersebut karena hasil penelitian tidak menunjukkan adanya pengaruh yang signifikan antara ukuran perusahaan dengan audit report lag. Hal ini mungkin disebabkan karena perusahaan yang besar belum tentu memiliki pengendalian internal yang lebih baik dibanding perusahaan yang lebih kecil dan auditor independen melaksanakan kewajiban profesionalnya tanpa dipengaruhi besarnya perusahaan yang diaudit.

Anggapan bahwa ukuran perusahaan akan mengurangi audit report lag muncul berdasarkan pandangan bahwa ukuran perusahaan yang besar cenderung memiliki kepentingan untuk menerbitkan laporan keuangannya lebih cepat dan biasanya memiliki pengendalian internal yang lebih baik sehingga akan memperpendek audit report lag dimana hal tersebut didukung oleh penelitian sebelumnya yang dilakukan oleh Hassan (2016), Alfraih (2016), Ayushabrina dan Rahardjo (2014), serta Ariyani dan Budiartha (2014) yang menemukan bahwa ukuran perusahaan berpengaruh negatif terhadap audit report lag.

Tetapi anggapan tersebut tidak didukung oleh bukti empiris pada sampel penelitian di Indonesia yang menunjukkan bahwa ukuran perusahaan mungkin saja memberikan pengaruh terhadap audit report lag tetapi tidak akan memberikan dampak yang signifikan. Hasil penelitian ini didukung oleh penelitian sebelumnya yang dilakukan oleh Haryani dan Wiratmaja (2014) dan Wardhani dan Raharja (2013) yang tidak menemukan adanya hubungan yang signifikan antara ukuran perusahaan dengan audit report lag.

\subsection{Pengaruh Kompleksitas Perusahaan Terhadap Audit Report Lag di Indonesia}

Kompleksitas perusahaan memiliki tingkat signifikansi 0,315 yang berarti lebih besar dari tingkat signifikansi (Sig > 0,05) maka dapat dilihat bahwa kompleksitas perusahaan tidak memiliki pengaruh signifikan terhadap audit report lag di Indonesia, sehingga $\mathrm{H}_{6}$ yang menyatakan adanya kompleksitas perusahaan akan meningkatkan audit report lag di Indonesia ditolak, karena hasil penelitian tidak menunjukkan adanya pengaruh yang signifikan antara kompleksitas perusahaan dengan audit report lag.

Hal ini mungkin disebabkan karena auditor independen melaksanakan kewajiban profesionalnya tanpa dipengaruhi kompleksitas operasi yang ada pada perusahaan yang diaudit. Potensi audit report lag yang lebih panjang, didasari oleh anggapan bahwa perusahaan dengan kompleksitas operasi yang tinggi maupun anak perusahaan yang lebih banyak akan cenderung menyelesaikan auditnya lebih lama, seperti pada hasil penelitian oleh Ariyani dan Budiartha (2014) yang menemukan bahwa kompleksitas perusahaan berpengaruh positif terhadap audit report lag. Namun, hal tersebut tidak ditemukan pada sampel perusahaan di Indonesia yang mengindikasikan bahwa meskipun mungkin saja kompleksitas perusahaan dapat mempengaruhi audit report lag, tetapi tidak menunjukkan adanya pengaruh yang signifikan antara keduanya. Hasil penelitian ini didukung penelitian sebelumnya yang dilakukan oleh 
Alfraih (2016) serta Wardhani dan Raharja (2013) yang menemukan kompleksitas operasi tidak berpengaruh signifikan terhadap audit report lag.

Tabel 4.16

Summary Hasil Regresi Kelompok Sampel di Malaysia

\begin{tabular}{|c|c|c|c|c|c|}
\hline \multicolumn{6}{|c|}{$\begin{array}{l}\text { ARL } \\
\text { 6,236SIZE }+225,999+1,357 \mathrm{BSIZE}-7,447 \mathrm{AUDCOM}-0,636 \mathrm{OWNCON}-4,464 \text { PROFIT }- \\
\end{array}$} \\
\hline \multicolumn{6}{|c|}{ Dependent Variable = Audit Report Lag } \\
\hline Independent Variable & $\begin{array}{l}\text { Expected } \\
\text { sign }\end{array}$ & Coefficients & t-stat & $\begin{array}{l}p \text {-value } \\
(1 \text { tailed })\end{array}$ & VIF \\
\hline Constant & & 225,999 & 17,144 & 0,000 & \\
\hline BSIZE & $(+)$ & 1,357 & 2,353 & $0,009 *$ & 1,334 \\
\hline AUDCOM & $(-)$ & $-7,447$ & $-4,422$ & $0,000 *$ & 1,139 \\
\hline OWNCON & $(+)$ & $-0,636$ & $-0,953$ & 0,171 & 1,017 \\
\hline PROFIT & $(-)$ & $-4,464$ & $-2,238$ & $\mathbf{0 , 0 1 3} *$ & 1,066 \\
\hline SIZE & $(-)$ & $-6,236$ & $-8,413$ & $0,000 *$ & 1,874 \\
\hline COMPLX & $(+)$ & 2,721 & 5,763 & $0,000 *$ & 1,576 \\
\hline \multicolumn{2}{|l|}{ F-Test } & 0,000 & & & \\
\hline \multicolumn{2}{|l|}{ Adjusted $R^{2}$} & 0,244 & & & \\
\hline \multicolumn{2}{|c|}{$\mathbf{N}$} & 361 & & & \\
\hline \multicolumn{3}{|c|}{ 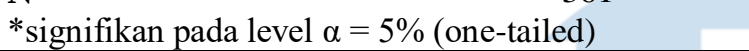 } & & & \\
\hline
\end{tabular}

Sumber : Hasil olahan Peneliti

\subsection{Pengaruh Board Size Terhadap Audit Report Lag di Malaysia}

Board size memiliki tingkat signifikansi 0,009 yang berarti lebih kecil dari tingkat signifikansi (Sig > 0,05) maka dapat disimpulkan bahwa board size memiliki pengaruh signifikan positif terhadap audit report lag, sehingga $\mathrm{H}_{7}$ yang menyatakan bahwa board size akan meningkatkan audit report lag di Malaysia tidak ditolak. Hal tersebut dikarenakan jumlah anggota dewan yang besar, justru dapat menyebabkan masalah koordinasi dan berkurangnya efektivitas kinerja anggota dewan yang akan meningkatkan audit report lag.

Hasil penelitian ini tidak mendukung hasil penelitian sebelumnya yang dilakukan oleh Alfraih (2016) yang menyatakan bahwa ukuran dewan yang lebih banyak cenderung memiliki audit report lag lebih pendek. Tetapi, penelitian ini didukung oleh penelitian sebelumnya yang dilakukan oleh Hassan (2016) serta Wardhani dan Raharja (2013) yang menemukan bahwa board size berpengaruh positif dengan audit report lag di Palestina. Hal ini juga sejalan dengan agency theory yang menyebutkan bahwa board size yang terlalu besar dapat menyebabkan timbulnya masalah koordinasi (Hassan 2016).

\subsection{Pengaruh Komite Audit Terhadap Audit Report Lag di Malaysia}

Komite audit memiliki tingkat signifikansi 0,000 yang berarti lebih kecil dari tingkat signifikansi (Sig > 0,05) maka dapat dilihat bahwa komite audit memiliki pengaruh signifikan negatif terhadap audit report lag, sehingga $\mathrm{H}_{8}$ yang menyatakan komite audit akan mengurangi audit report lag di Malaysia tidak ditolak. Hal tersebut dikarenakan efektivitas komite audit akan meningkatkan kualitas laporan keuangan sehingga mengurangi audit report lag.

Hasil penelitian ini mendukung hasil penelitian sebelumnya yang dilakukan oleh Hassan (2016), Puasa, et al. (2014), Ayushabrina dan Rahardjo (2014), Haryani dan Wiratmaja (2014), serta Apadore dan Noor (2013) yang menyatakan bahwa keberadaan komite audit dalam suatu perusahaan dapat meningkatkan kualitas laporan keuangan suatu perusahaan sehingga dapat mengurangi audit report lag. Tetapi penelitian ini tidak didukung oleh penelitian sebelumya yang dilakukan oleh Wardhani dan Raharja (2013) serta Angruningrum dan Wirakusuma (2013) yang menyatakan komite audit tidak berpengaruh terhadap audit report lag. 


\subsection{Pengaruh Ownership Concentration Terhadap Audit Report Lag di Malaysia}

Ownership concentration memiliki tingkat signifikansi 0,171 yang berarti lebih besar dari tingkat signifikansi (Sig > 0,05) maka dapat disimpulkan bahwa ownership concentration tidak memiliki pengaruh signifikan terhadap audit report lag di Malaysia sehingga $\mathrm{H}_{9}$ yang menyatakan adanya konsentrasi kepemilikan akan meningkatkan audit report lag di Malaysia ditolak, karena hasil penelitian tidak menunjukkan adanya hubungan yang signifikan atas pengaruh ownership concentration terhadap audit report lag.

Hasil penelitian tersebut sejalan dengan penelitian yang dilakukan Hassan (2016) yang menemukan bahwa ownership concentration tidak berpengaruh signifikan terhadap audit report lag. Hal itu mungkin dikarenakan kepemilikan saham yang terkonsentrasi pada perusahaan di Malaysia tidak mempengaruhi kualitas laporan keuangan maupun pengungkapannya, sehingga tidak ditemukannya pengaruh yang signifikan terhadap audit report lag.

\subsection{Pengaruh Laba Tahun Berjalan Terhadap Audit Report Lag di Malaysia}

Laba atau rugi tahun berjalan memiliki tingkat signifikansi 0,013 yang berarti lebih kecil dari tingkat signifikansi (Sig > 0,05) maka dapat disimpulkan bahwa laba atau rugi tahun berjalan memiliki pengaruh signifikan negatif terhadap audit report lag di Malaysia, sehingga $\mathrm{H}_{10}$ yang menyatakan bahwa laba tahun berjalan akan mengurangi audit report lag di Malaysia tidak ditolak. Hal tersebut dikarenakan laba mencerminkan kinerja perusahaan yang baik dan dianggap sebagai good news bagi manajemen maupun investor, sehingga perusahaan cenderung sesegera mungkin mempublikasikan laporan keuangannya.

Hasil penelitian ini mendukung penelitian sebelumnya yang dilakukan oleh Aristika dkk., (2016) serta Shukeri dan Islam (2012) yang menemukan bahwa laba tahun berjalan akan mengurangi audit report lag, yang berarti perusahaan yang mengalami laba, akan cenderung mempublikasikan laporan keuangannya lebih cepat. Tetapi, hasil penelitian ini tidak memberikan bukti yang mendukung penelitian yang dilakukan oleh Ayushabrina dan Raharjo (2014) serta Indriyani dan Supriyati (2012) yang menyatakan bahwa tidak ada pengaruh yang signifikan antara laba tahun berjalan dengan audit report lag.

\subsection{Pengaruh Ukuran Perusahaan Terhadap Audit Report Lag di Malaysia}

Ukuran perusahaan memiliki tingkat signifikansi 0,000 yang berarti lebih kecil dari tingkat signifikansi ( $\mathrm{Sig}>0,05)$ maka dapat disimpulkan bahwa ukuran perusahaan memiliki pengaruh signifikan negatif terhadap audit report lag di Malaysia, sehingga $\mathrm{H}_{11}$ yang menyatakan ukuran perusahaan akan mengurangi audit report lag di Malaysia tidak ditolak. Hal tersebut dikarenakan ukuran perusahaan yang besar cenderung memiliki kepentingan untuk menerbitkan laporan keuangannya lebih cepat dan biasanya memiliki pengendalian internal yang lebih baik sehingga akan memperpendek audit report lag.

Hasil penelitian ini mendukung oleh penelitian sebelumnya yang dilakukan oleh Hassan (2016), Alfraih (2016), Ayushabrina dan Rahardjo (2014), serta Ariyani dan Budiartha (2014) yang menemukan bahwa ukuran perusahaan berpengaruh negatif terhadap audit report lag. Tetapi tidak mendukung penelitian sebelumnya yang dilakukan oleh Haryani dan Wiratmaja (2014) serta Wardhani dan Raharja (2013) yang tidak menemukan adanya hubungan yang signifikan antara ukuran perusahaan dengan audit report lag.

\subsection{Pengaruh Kompleksitas Perusahaan Terhadap Audit Report Lag di Malaysia}

Kompleksitas perusahaan memiliki tingkat signifikansi 0,000 yang berarti lebih kecil dari tingkat signifikansi (Sig > 0,05) maka dapat disimpulkan bahwa kompleksitas perusahaan memiliki pengaruh signifikan positif terhadap audit report lag di Malaysia, sehingga $\mathrm{H}_{12}$ yang menyatakan adanya kompleksitas perusahaan akan meningkatkan audit report lag di Malaysia 
tidak ditolak. Hal tersebut karena perusahaan dengan kompleksitas operasi yang tinggi maupun anak perusahaan yang lebih banyak akan cenderung menyelesaikan auditnya lebih lama.

Hasil penelitian ini didukung oleh penelitian sebelumnya yang dilakukan oleh Ariyani dan Budiartha (2014), yang menemukan bahwa perusahaan yang lebih komlpleks operasinya akan cenderung menghasilkan audit report lag yang lebih panjang. Tetapi hasil penelitian ini tidak mendukung penelitian sebelumnya yang dilakukan oleh Alfraih (2016) serta Wardhani dan Raharja (2013) yang tidak menemukan adanya hubungan signifikan antara kompleksitas operasi dengan audit report lag serta penelitian yang dilakukan Hassan (2016) yang menemukan bahwa kompleksitas perusahaan berpengaruh negatif terhadap audit report lag

\section{KESIMPULAN}

Penelitian ini bertujuan untuk menguji tentang faktor-faktor yang mempengaruhi audit report lag pada perusahaan yang terdaftar di Bursa Efek Indonesia dan Bursa Malaysia tahun 2015. Pengujian dilakukan dengan menggunakan analisis regresi linier berganda dengan enam variabel independen, diantaranya jumlah anggota dewan, komite audit, ownership concentration, laba atau rugi tahun berjalan, ukuran perusahaan dan kompleksitas perusahaan. Berdasarkan hasil penelitian dan pembahasan yang telah dilakukan, maka dapat disimpulkan bahwa:

1. Jumlah anggota dewan akan mengurangi audit report lag di Indonesia tetapi akan meningkatkan audit report lag di Malaysia. Di Indonesia, jumlah anggota dewan yang lebih banyak dengan latar belakang yang keahlian beragam diperlukan untuk mengurangi audit report lag, namun pada sampel penelitian di Malaysia, hal tersebut justru dapat menyebabkan masalah koordinasi yang akan meningkatkan audit report lag.

2. Komite audit akan mengurangi audit report lag di Malaysia tetapi tidak memiliki pengaruh yang signifikan terhadap audit report lag di Indonesia. Hal itu terlihat dari signifikansi variabel komite audit pada sampel penelitian di Malaysia yang menunjukkan bahwa efektivitas komite audit akan meningkatkan kualitas laporan keuangan sehingga mengurangi audit report lag, namun pada sampel penelitian di Indonesia, efektivitas komite audit tidak menunjukkan adanya kontribusi yang signifikan untuk mengurangi audit report lag.

3. Adanya konsentrasi kepemilikan akan meningkatkan audit report lag di Indonesia, tetapi tidak memiliki pengaruh yang signifikan terhadap audit report lag di Malaysia. Hal itu terlihat dari signifikansi variabel ownership concentration pada sampel penelitian di Indonesia yang menunjukkan bahwa perusahaan dengan kepemilikan yang terkonsentrasi cenderung memiliki kualitas pelaporan serta pengungkapan yang rendah sehingga akan meningkatkan audit report lag, sedangkan pada sampel penelitian di Malaysia, konsentrasi kepemilikan tidak menunjukkan adanya kontribusi yang signifikan dalam meningkatkan audit report lag.

4. Laba tahun berjalan akan meningkatkan audit report lag di Indonesia dan Malaysia. Hal tersebut dapat dilihat dari signifikansi variabel laba atau rugi tahun berjalan pada kedua kelompok sampel penelitian di Indonesia dan Malaysia yang menunjukkan bahwa perusahaan yang mengalami laba cenderung akan mempublikasikan laporan keuangannya lebih cepat.

5. Ukuran perusahaan akan mengurangi audit report lag di Malaysia, tetapi tidak memiliki pengaruh yang signifikan terhadap audit report lag di Indonesia. Hal tersebut dapat dilihat dari signifikansi variabel ukuran perusahaan pada sampel penelitian di Malaysia yang menunjukkan ukuran perusahaan yang besar cenderung memiliki kepentingan untuk 
menerbitkan laporan keuangannya lebih cepat dan biasanya memiliki pengendalian internal yang lebih baik sehingga akan memperpendek audit report lag, sedangkan pada sampel penelitian di Indonesia, besar kecilnya perusahaan tidak mempengaruhi audit report lag.

6. Adanya kompleksitas perusahaan akan meningkatkan audit report lag di Malaysia, tetapi tidak memiliki pengaruh yang signifikan terhadap audit report lag di Indonesia. Hal tersebut dapat dilihat dari signifikansi variabel kompleksitas perusahaan pada sampel penelitian di Malaysia yang menunjukkan perusahaan dengan kompleksitas operasi yang tinggi maupun anak perusahaan yang lebih banyak akan cenderung menyelesaikan auditnya lebih lama, sedangkan pada sampel penelitian di Indonesia, kompleksitas perusahaan tidak mempengaruhi audit report lag.

7. Secara keseluruhan, hasil penelitian ini menemukan bahwa audit report lag di Indonesia dan Malaysia dipengaruhi oleh beberapa faktor yang berbeda, dimana perbedaan tersebut dapat disebabkan karena adanya perbedaan budaya perusahaan, lingkungan ekonomi, maupun regulasi yang ada pada kedua negara.

\section{REFERENSI}

Alfraih, M. M. 2016. Corporate Governance Mechanism and Audit Delay in a Joint Audit Regulation. Journal of Financial Regulation and Compliance, Vol. 24 Iss 3 pp. $292-316$

Angruningrum, S. \& W. Made Gede.(2013). Pengaruh Profitabilitas, Leverage, Kompleksitas Operasi, Reputasi KAP dan Komite Audit Terhadap Audit Delay. Jurnal Akuntansi. Universitas Udayana. Vol 5.2.

Apadore, K. \& N. M. Mohd. (2013). Determinants of Audit Report Lag and Corporate Governance in Malaysia. International Journal of Business and Management. Vol. 8, No. 15; 2013. E-ISSN: 1833-8119.

Aristika, M. N., T. Rina \& H. C. Dewi.(2016). Pengaruh Opini Audit, Ukuran Perusahaan, Umur Perusahaan, dan Laba Rugi Terhadap Audit Report Lag. Syariah Paper Accounting FEB UMS. ISSN: 2460-0784.

Ariyani, N. N. T. D. \& B. I Ketut. (2014). Pengaruh Profitabilitas, Ukuran Perusahaan, Kompleksitas Operasi Perusahaan dan Reputasi KAP Terhadap Audit Report Lag Pada Perusahaan Manufaktur. Jurnal Akuntansi. Universitas Udayana. Vol 8.2.

Ashton, R., Wilingham, J., \& Elliot, R. (1987). An Empirical Analysis of Audit Delay. Journal of Accounting Research, Vol. 25, No. 2, 275-292

Ayushabrina, F. dan R. S. Nur. (2014). Pengaruh Faktor Internal dan Eksternal Perusahaan terhadap Audit Report Lag. Jurnal Akuntansi Fakultas Ekonomika dan Bisnis. Universitas Diponegoro. Vol 3, No. 2, 2014, pp. 1-12

BAPEPAM-LK. (2011) Keputusan Ketua Badan Pengawas Pasar Modal dan Lembaga Keuangan Nomor: KEP-346/BL/2011. Diakses pada 15 November 2016, dari http://www.ojk.go.id.

BAPEPAM-LK. (2012). Keputusan Ketua Badan Pengawas Pasar Modal dan Lembaga Keuangan Nomor: KEP-643/BL/2012. Diakses pada 15 November 2016, dari http://www.ojk.go.id.

Bezemer, P. J, Peji, S., de Krujis, L., \& M. Gregory F. (2014). How Two-tier Board Can Be More Effective. Corporate Governance : The International Journal of Business in Society, 14(1), pp. 15-31.

Bursa Malaysia. Bursa Malaysia Listing Requirement. Diakses pada 11 Maret 2017, dari http://www.bursamalaysia.com. 
CNN Indonesia. (2016). Telat Sampaikan Lapkeu, BEI Suspensi 18 Perusahaan. Diakses melalui http://www.cnnindonesia.com/ekonomi/2016063014504 5-92-142141/telatsampaikan-lapkeu-bei-suspensi-saham-18-perusahaan, pada tanggal 10 November 2016 pukul 22:17 WIB.

Harahap, S. S. (2012). Teori Akuntansi: Edisi Revisi 2011. Jakarta: PT Rajagrafindo Persada.

Haryani, J. \& W. I Dewa Nyoman. (2014). Pengaruh Ukuran Perusahaan, Komite Audit, Penerapan International Financial Reporting Standards dan Kepemilikan Publik pada Audit Delay. Universitas Udayana. Vol 6.1.

Hashim, U. J. B. \& Rahman, R. B. A. (2011). Audit Report Lag and the Effectiveness of Audit Committee Among Malaysian Listed Companies. International Bulletin of Business Andiminstration, ISSN: 1451-243X

Hassan, Y. M. (2016). Determinants of Audit Report Lag: Evidence from Palestine. Journal of Accounting in Emerging Economies, Vol. 6 No. 1, pp. 13-32. DOI: 10.1108/JAEE-052013-0024

Ikatan Akuntan Indonesia. (2015). Standar Akuntansi Keuangan. Jakarta: Salemba Empat.

Indriyani, R. E. \& Supriyati. (2012). Faktor-Faktor yang Mempengaruhi Audit Report Lag Perusahaan Manufaktur di Indonesia dan Malaysia. The Indonesian Accounting Review, Volume 2 No. 2, July 2012, pp 185-202.

International Finance Corporation Advisory Services in Indonesia. (2014). The Indonesia Corporate Governance Manual. Jakarta: International Finance Corporation Indonesia.

Jensen, M. C. \& Meckling, W. H. (1976). Theory of The Firm : Managerial Behavior, Agency Costs and Ownership Structure. Journal of Financial Economics. Vol 3 (1976) p305-360.

Koran Sindo .(2016). BEI Siapkan Integrasi Pasar Modal ASEAN. Diakses melalui http://koran-sindo.com/page/news/2016-01-05/2/3/BEI_Siapkan_

Integrasi_Pasar_Modal_ASEAN, pada tanggal 23 Maret 2016 pukul 23:00 WIB.

Plessis, J.J.D., Grobfeld, B., Lutterman, C., Saenger, I., Sandrock, O., Casper, M. (2012). German Corporate Governance in International and European Context. German: Springer.

Puasa, S., Salleh, M. F. Md, \& Ahmad, A. (2014). Audit Committee and Timeliness of Financial Reporting: Malaysian Public Listed Company. Middle-East Journal of Scientific Research. ISSN: 1990-9233.

Ramdhaningsih, A. \& Utama, I. M. K. (2013). Pengaruh Indikator Good Corporate Governance dan Profitabilitas Pada Pengungkapan Corporate Social Responsibility. Universitas Udayana. Vol 3.2, 2013.

Sari, R. R. \& Ghozali, I. (2014). Faktor-faktor Pengaruh Audit Report Lag (Kajian Empiris Pada Perusahaan Manufaktur Yang Terdaftar di Bursa Efek Indonesia Tahun 2010-2012). Jurnal Akuntansi Fakultas Ekonomika dan Bisnis. Universitas Diponegoro. Vol 3, No. 2, 2012, pp. 1.

Shukeri, S. \& Islam, Md. A. (2012). The Determinants of Audit Timeliness : Evidence from Malaysia. Journal of Applied Sciences Research. Vol 8(7). ISSN: 1819-544X.

Wardhani, A. P. \& Raharja, S. (2013). Analisis Pengaruh Corporate Governance Terhadap Audit Report Lag. Jurnal Akuntansi Fakultas Ekonomika dan Bisnis, Universitas Diponegoro. Vol 2, No. 3, 2013, p. 1.

Widhiasari, N. M. S. \& Budiartha, I. K. (2016), Pengaruh Umur Perusahaan, Ukuran Perusahaan, Reputasi Auditor, dan Pergantian Auditor Terhadap Audit Report Lag. Jurnal Akuntansi. Universitas Udayana. Vol 15.1. 2016. 